\title{
Repercussão Geral: Acesso à Justiça e Prazo Razoável na Prestação Jurisdicional
}

João Carlos Saud Abdala Filho

\section{RESUMO}

$\mathrm{O}$ acesso à justiça, inserido no artigo $5^{\circ}$, inciso XXXV, da Constituição Federal, é um direito fundamental que garante a todos os cidadãos não apenas o ingresso em juízo, mas o término do processo com a pretensão satisfeita dentro de um razoável lapso de tempo. A razoável duração do processo é outro direito fundamental expresso no mesmo artigo $5^{\circ}$, introduzido pela Emenda Constitucional n ${ }^{\circ} 45 / 2004$. Este assegura que os processos sejam rápidos e, mais do que isso, eficientes na medida em que garante a Justiça às partes em menor intervalo de tempo. Nesse diapasão, o processo deve ser justo (garantindo às partes a correta solução da lide) e rápido, pois de nada adianta uma solução tardia ao conflito. Foi, também, a Emenda Constitucional $\mathrm{n}^{\circ} 45$ a responsável por instituir a repercussão geral como requisito para o recurso extraordinário (art. $102, \S 3^{\circ}$ da $\mathrm{CF}$ ), exigindo a demonstração de que a matéria versada ultrapassa os interesses subjetivos da causa. Objetiva-se com isso diminuir o número de processo que sobem ao Supremo Tribunal Federal, para que este possa, como órgão supremo que o é, decidir causas de real interesse nacional e criar precedentes de qualidade a serem usados por outros órgãos hierarquicamente inferiores. Sob o aspecto constitucional, nada mais é do que o resultado do verdadeiro direito ao acesso à justiça e à razoável duração do processo, haja vista que visa garantir soluções justas e rápidas aos processos que não comportam mais recursos protelatórios e proporcionar um exame de melhor qualidade àqueles que ainda necessitam de apreciação pelo órgão supremo.

Palavras-chave: acesso à justiça; razoável duração do processo; celeridade processual; repercussão geral.

\section{ABSTRACT \\ General Repercussion: Access to justice and reasonable term on the jurisdictional provision}

The Access to justice, inserted on the 5th article, incise XXXV of the Federal Constitution, is a fundamental right that guarantees to all citizens not only the admission in court, but also the termination of the process with the satisfied pretension in a reasonable period of time. The reasonable duration of the process is another fundamental right expressed on the same article $5^{\text {th }}$, introduced by the Constitutional Amendment n. 45/2004. This article guarantees that the processes are fast and, more than that, efficient because of the fact that it guarantees justice to both parties in a shorter period of time. As such, the process should be fair (it must guarantee to both parties the correct solution of the litigious matter) and fast because a late solution for the conflict may be useless. It was also the Constitutional Amendment n. 45 the one responsible for instituting the general repercussion as a requirement for the extraordinary appeal (art. 102, $\$ 3$ of the Federal Constitution) - it requires the demonstration that the subject in discussion exceeds the subject interests of the cause. The main goal is to diminish the number of processes that reaches the Supreme Federal Court so that it can, as a Supreme Organism, deal with causes of real national interest and thus create quality precedents which could be used by other Organisms of inferior hierarchy. Under the constitutional aspect, it is nothing else than the result of a truly right of access to justice and the reasonable duration of process, considering that it aims to guarantee fair and fast solutions to the processes that do 
not require any other postponing appeals and provide a better quality examination to the ones that still need appreciation by the Supreme Organism.

Keywords: access to justice; reasonable duration of process; procedure celerity; general repercussion

\section{Introdução}

Já se tornou lugar comum o debate acerca da morosidade da justiça. Todos sabem que o procedimento a ser enfrentado para a solução dos conflitos pelo Poder Judiciário é extremamente complexo e somados os mais diversos fatores, como a falta de estrutura e pessoal, torna-se lento.

Isso não é novidade para ninguém, porém o que não se pode esquecer é que o Estado tomou para si o papel de solucionador dos conflitos entre particulares, proibindo que houvesse a autotutela. Assim, ele é responsável por dar às partes que recorrem ao Judiciário o que lhes realmente é devido.

Ocorre que nenhuma sociedade formada por diversos tipos de pessoas é isenta de conflitos. Todas, devido à grande complexidade das relações pessoais, possuem conflitos de interesse de diversas naturezas - comercial, civil, criminal, tributária, etc. - e precisam que estes sejam solucionados para que assim tal sociedade seja segura, justa e evoluída.

Com efeito, uma sociedade que consiga resolver suas lides de modo eficiente é justa porque concede às partes a solução que buscam ingressando no Judiciário. É segura porque a sociedade que possui um Poder Judiciário firme e correto é capaz de resolver todos conflitos decorrentes e garantir a ordem jurídica, ensejando assim investimentos e benfeitorias para ela, e desse modo, evoluindo.

Nesse contexto, a sociedade brasileira está muito longe de possuir um Judiciário apto a ensejar tais vantagens. Mas, por isso, o direito processual brasileiro está a todo o momento sendo reformado, a fim de se conseguir um processo mais célere e, junto a isso, efetivo, garantindo a tão buscada justiça.

Justiça deve ser entendida como algo muito maior que a simples aplicação da lei ao caso concreto. Outros fatores devem ser incorporados a tal definição, como fator satisfação das partes e tempo. Nem sempre uma lei elaborada corretamente no seu aspecto formal é justa.

Desde seu surgimento, o Código de Processo Civil vem sendo modificado, eliminando ou incluindo elementos. Grandes alterações surgiram a fim de facilitar os procedimentos já existentes e incluir novos como, por exemplo, a tutela antecipada pela Lei $n^{\circ}$ 
8.952, de 13 de dezembro de 1994, e o procedimento monitório pela Lei $\mathrm{n}^{\circ}$ 9.079, de 14 de julho de 1995.

Não é para menos, a resolução de uma causa pelo Judiciário leva vários anos, sendo que, às vezes, ultrapassa os vinte. Diversos são os motivos que atrapalham o trâmite processual normal, como a falta de estrutura do poder judiciário, a grande quantidade de formalidades no processo judicial, entre outros motivos.

Essa crise, por sua vez, não escapa do âmbito do órgão máximo da Justiça brasileira, o Supremo Tribunal Federal (STF). Segundo estatística oferecida pelo próprio órgão, nos últimos anos este foi abarrotado de recursos. Em 2006, recebeu 127.535 processos. Já em 2007, 91.003 processos foram recebidos até setembro deste ano ${ }^{1}$.

São inúmeros processos para serem julgados por um órgão composto por somente onze ministros. Assim é impossível que ele cumpra sua função de resolver questões de suma importância com grande qualidade, ou seja, não há tempo suficiente para que os julgadores pesquisem e estudem a matéria, para decidir da melhor forma possível para a Justiça.

Nesse diapasão, diversas modificações foram criadas e outras são propostas para reter a grande quantidade de recursos que se dirigem ao Supremo. Com a Emenda Constitucional (EC) $\mathrm{n}^{\mathrm{o}} 45$ de 08.12.2004, passou-se a exigir para a admissão do recurso extraordinário pelo STF, a demonstração da repercussão geral da questão constitucional.

Em 19 de dezembro de 2006, a Lei $\mathrm{n}^{\circ} 11.418$ regulamentou o assunto, estabelecendo o procedimento a ser incorporado ao Código de Processo Civil, e sobre o assunto prescreve que para efeito da repercussão geral, será considerada a existência, ou não, de questões relevantes do ponto de vista econômico, político, social ou jurídico que ultrapassem os interesses subjetivos da causa.

Da mesma forma, regulamentando a repercussão geral, as Emendas Regimentais (ER) $n^{\circ} 21$ de 2007 e no 23 de 2008, acresceram ao Regimento Interno do STF (RISTF) disposições relativas àquela, a fim de que realmente pudesse ser exigida.

A novidade causa uma discussão de ordem constitucional. A mesma emenda que colocou no ordenamento jurídico a repercussão geral, também adicionou ao rol de direitos e garantias individuais, o direito à razoável duração dos processos e os meios que garantam a celeridade de sua tramitação (artigo 5, LXXVIII, da Constituição Federal).

\footnotetext{
${ }^{1}$ Supremo Tribunal Federal: $\quad$ Estatísticas. Brasil. Disponível em: $<$ http://www.stf.gov.br/portal/cms/verTexto.asp?servico=estatistica\&página=REAIProcessoDistribuido $>$. Acesso em: 11 abr. 2008.
} 
Ocorre que, para uns, este requisito de admissibilidade do recurso extraordinário é decorrência do princípio da celeridade, combinado com o efetivo acesso à Justiça, garantindo este acesso a todos, bem como um resultado solucionador da lide, de modo justo e tempestivo.

Mas, para outros, o requisito restringe o direito, também consagrado no rol do artigo $5^{\circ}$ da Constituição Federal, à ampla defesa, haja vista que este assegura a todos os litigantes em processo judicial e administrativo, e aos acusados em geral, o contraditório e a ampla defesa, com os meios e recursos a ela inerentes (inciso LV, da referida norma).

Alegam que se o recurso não for admitido por falta de repercussão geral estaria se criando um óbice para a decisão de mérito do processo pelo Supremo Tribunal Federal e conseqüentemente ferindo o direito de ampla defesa e outros direitos e garantias fundamentais.

A solução deste conflito aparente de normas constitucionais exige um estudo aprofundado de todos estes elementos, e, assim, utilizando-se da ponderação no choque de princípios, a questão deve ser estudada da maneira que mais garanta a Justiça, justa e célere.

\section{0 tempo no direito processual civil e a morosidade da justiça}

O tempo dentro do processo civil brasileiro deve ser visto como um fator de suma importância para a realização da justiça, afinal é inerente a qualquer procedimento o transcurso de certo lapso de tempo. Com razão assegura Gajardoni que

\footnotetext{
É chegado o momento do tempo do processo 'tomar seu efetivo lugar dentro da ciência processual, pois este não pode deixar de influir sobre a elaboração dogmática preocupada com a construção do processo justo ou com aquele destinado a realizar concretamente os valores e os princípios contidos na Constituição da República'. ${ }^{2}$
}

Nesse sentido e corroborando o entendimento que destaca a importância do tempo no processo, Marinoni leciona que

É preciso que ao tempo do processo seja dado o seu devido valor, já que, no seu escopo básico de tutela dos direitos, o processo será mais efetivo, ou terá uma maior capacidade de eliminar com justiça as situações de conflito, quanto mais prontamente tutelar o direito do autor que tem razão. ${ }^{3}$

\footnotetext{
${ }^{2}$ GAJARDONI, Fernando da Fonseca. Técnicas de aceleração do processo. São Paulo: Lemos e Cruz, 2003. p. 39.

${ }^{3}$ MARINONI, Luiz Guilherme. Tutela antecipatória, julgamento antecipado e execução imediata da sentença. São Paulo: Revista dos Tribunais, 1997. p. 17.
} 
De tal modo, torna-se imperiosa a resolução de um processo judicial dentro de um curto período de tempo, observando-se as exigências legais e os direitos e garantias constitucionais, eis que uma decisão tempestiva traduz-se em um pressuposto de um processo justo.

Isto porque, não há justiça quando uma decisão é dada pelo Poder Judiciário, mesmo que for a mais correta do ponto de vista legal, quando não houver mais interesse das partes e quando não for mais necessária. Conforme ensina José Rogério Cruz e Tucci:

\footnotetext{
Um julgamento tardio irá perdendo progressivamente seu sentido reparador, na medida em que se postergue o momento do reconhecimento judicial de direito; e, transcorrido o tempo razoável para resolver a causa, qualquer solução será, de modo inexorável, injusta, por maior que seja o mérito científico do conteúdo da decisão. ${ }^{4}$
}

Várias são as consequiências da intempestividade da tutela jurisdicional, pois, no mais das vezes, a parte mais forte (rica) é a que se beneficia. Essa demora também sempre favorece o réu que não tem razão, pois a dilatação do processo faz com que ele mantenha o status quo ante e, também, lucre como, por exemplo, quando permanece indevidamente em poder da coisa, colhendo os frutos. ${ }^{5}$

Ocorre que o Poder Judiciário brasileiro está em crise decorrente, justamente, da prestação intempestiva da tutela jurisdicional por conta da morosidade processual. Até transitar em julgado a decisão de uma ação, certamente, bons anos se passam, já que o processo, devido as amplas oportunidades de recursos amparados pela legislação processual, pode passar por até quatro instâncias de magistrados.

Outros fatores contribuem para a crise processual civil, como a falta de estrutura e a desorganização judiciária, verificada na necessidade de criação de novas varas, falta de juízes e de servidores - e até despreparo destes -, estrutura arcaica, na maioria dos fóruns, precisando de espaços e de equipamentos informáticos.

Além disto, houve um grande aumento no número de demandas em apreciação pelo Poder Judiciário decorrentes das relações humanas complexas surgidas com a globalização

\footnotetext{
${ }^{4}$ TUCCI, José Rogério Cruz e. Garantia do processo sem dilações indevidas, in TUCCI, José Rogério Cruz e (org.). Garantias constitucionais do processo civil: Homenagem aos 10 anos da Constituição Federal de 1988. São Paulo: Revista dos Tribunais, 1989. p. 235-236.

${ }_{5}$ Cf. MARINONI, Luiz Guilherme, Tutela antecipatória, julgamento antecipado e execução imediata da sentença. São Paulo: Revista dos Tribunais, 1997. p. 22-24.
} 
dos mercados, bem como da facilitação de acesso à justiça a todos, por meio de diversos mecanismos, como a assistência judiciária gratuita aos necessitados.

A Constituição Federal de 1988, por sua vez, ao garantir diversos direitos, fez com que os números de ações multiplicassem, pois os cidadãos buscam através do Poder Judiciário, a concretização dos mesmos. Destaca-se, ainda, que as exigências, na legislação processual, de várias formalidades para realização dos atos processuais é outra barreira a ser enfrentada.

O Poder Judiciário não se aparelhou para tutelar tantas demandas surgidas nos últimos tempos. No âmbito dos tribunais superiores, a crise persiste em razão das diversas possibilidades de recursos previstas nas leis processuais e pelas mesmas dificuldades estruturais e de organização judiciária.

Apenas o art. 496 do Código de Processo Civil (CPC) estabelece oito tipos de recursos. Além destes, há outros previstos em normas especiais e em regimentos internos dos Tribunais, como o agravo regimental. Ressalte-se, ainda, que, na falta de recurso, a parte pode utilizar a correição parcial e o mandado de segurança.

Por tais motivos, ocorreram diversas reformas no Código de Processo Civil, conhecidas como minirreformas, todas visando conferir a ele um caráter mais célere e mais instrumentalista.

Estas alterações no processo civil brasileiro vêm desde a publicação do CPC em 1973, já que a Lei $\mathrm{n}^{\circ} 5.925$, de $1^{\circ}$ de outubro de 1973 alterou o referido diploma, antes mesmo de entrar em vigor, em quase cem artigos.

Faz-se mister citar as Leis $\mathrm{n}^{\circ} 11.417 / 06,11.418 / 06$ e 11.672/08, referentes, respectivamente, à súmula vinculante, repercussão geral das questões constitucionais no recurso extraordinário e ao julgamento de recursos repetitivos no âmbito do Superior Tribunal de Justiça.

Além das reformas realizadas na legislação infraconstitucional, a Emenda Constitucional $n^{\circ} 45$, de 08 de dezembro de 2004, conhecida como a Reforma do Judiciário, modificou diversos artigos referentes à organização do Poder Judiciário na CF, destacando-se a introdução, do direito à razoável duração do processo e a exigência da repercussão geral para o recurso extraordinário.

Analisando as mudanças ocorridas, o doutrinador Humberto Theodoro Júnior aduz que: 
Toda uma grande reforma se fez, nos últimos anos, nos textos do Código de Processo Civil, com o confessado propósito de desburocratizar o procedimento e acelerar o resultado da prestação jurisdicional. Legislação extravagante também cuidou de criar ações novas e remédios acauteladores visando a ampliar o espectro da tutela jurisdicional, de modo a melhor concretizar a garantia do amplo e irrestrito acesso à justiça, tornado direito fundamental pelas Constituições democráticas, tanto em nosso país como no direito comparado. Até a própria Constituição foi emendada para acrescer no rol dos direitos fundamentais a garantia de uma razoável duração para o processo e o emprego de técnicas de aceleração da prestação jurisdicional. ${ }^{6}$

\section{A garantia da celeridade processual e do acesso à justiça}

\subsection{Celeridade processual}

A celeridade processual consiste em formas e meios capazes de eliminar obstáculos, formalidades inúteis e qualquer outra circunstância que atrapalhe o regular desenvolvimento do processo judicial, para que o Poder Judiciário preste com maior eficiência e rapidez a jurisdição. Em suma: consiste em acelerar o andamento do processo.

Atualmente o princípio da razoável duração do processo serve de base para promover a celeridade processual. Por isto diversas modificações na legislação de processo civil foram realizadas, buscando diminuir o tempo de duração do trâmite jurisdicional.

Não obstante, antes mesmo da introdução do inciso LXXVIII no art. $5^{\circ}$ da Constituição Federal, que trata da garantia da razoável duração do processo, o princípio do devido processo legal já consagrava a celeridade processual.

A Convenção Americana sobre Direitos Humanos, aprovada na Conferência de São José da Costa Rica, em 22.11.1969 (recepcionada em 1992 pelo Brasil) também versou sobre celeridade processual e prescreve que "toda pessoa tem direito a ser ouvida com as devidas garantias e dentro de um prazo razoável, por um juiz ou um tribunal competente, independente e imparcial, estabelecido anteriormente por lei, na apuração de qualquer acusação penal formulada contra ela ou para que se determinem seus direitos ou obrigações de natureza civil, trabalhista, fiscal ou de qualquer outra natureza”.

Foi a EC no 45/2004 que, a fim de promover a esperada reforma do judiciário, adicionou ao artigo $5^{\circ}$ da Constituição Federal, o inciso LXXVIII, garantindo expressa e indiscutivelmente que "a todos, no âmbito judicial e administrativo, são assegurados a razoável duração do processo e os meios que garantam a celeridade de sua tramitação”.

\footnotetext{
6 THEODORO JÚNIOR, Humberto. Curso de direito processual civil. 46. ed. Rio de Janeiro: Forense,
} 2007. v. I. p. 9. 
Por tratar-se de direito fundamental, inserido no art. $5^{\circ}$ da Constituição Federal, o preceito da razoável duração do processo é direcionado a todos os Poderes estatais, servindo como mandamento constitucional. Quanto ao tema leciona Fernando da Fonseca Gajardoni:

\begin{abstract}
Já na dimensão objetiva, tem-se que a garantia do processo sem dilações indevidas não é uma mera declaração de intenções dirigidas ao Judiciário, mas sim uma autêntica norma programática, cujo mandamento deve ser cumprido por todos os Poderes do Estado. Ao Poder Legislativo, é exigida uma especial atenção ao elemento temporal, no momento de elaborar a legislação processual aplicável. Ao Poder Executivo, a tarefa de articular a estrutura orgânica e material necessária para a função jurisdicional e dar apoio completo na execução dos julgados. E, finalmente, ao Poder Judiciário incumbe utilizar, de forma eficiente, os meios postos à sua disposição, bem como cumprir rigorosamente os prazos processuais. ${ }^{7}$
\end{abstract}

Indagação importante surge ao se questionar qual é a quantidade de tempo necessária para que a duração do processo seja razoável, conforme estabelece o art. $5^{\circ}$, LXXVIII, da CF. Apesar de não existir uma definição exata, sabe-se que deve ser utilizado o princípio da razoabilidade no caso concreto.

Existem diversos posicionamentos doutrinários, sendo um deles o estabelecido pela Convenção Européia dos Direitos do Homem que diz que, salvo os casos específicos, existem três critérios a serem utilizados para estabelecer o sentido de razoável no caso concreto: a) complexidade do assunto; b) o comportamento dos litigantes e de seus procuradores; c) a atuação do órgão jurisdicional. Há quem inclua, como Fernando da Fonseca Gajardoni, um quarto fator, qual seja, a importância do objeto do processo para o recorrente, nos casos de fixação do quantum indenizatório.

O citado jurista entende que tempo ideal do processo é a soma dos prazos fixados pelo Código de Processo Civil mais o tempo de trânsito dos autos. Conclui notadamente que:

(...) é tempestiva a tutela jurisdicional quando os prazos legalmente prefixados para o trâmite e instrução do processo, concebidos em vista das circunstâncias de fato da demanda, do direito a ser protegido, do contraditório e da ampla defesa, são cumpridos pelas partes e pelo órgão jurisdicional. ${ }^{8}$

7 GAJARDONI, Fernando da Fonseca. O princípio constitucional da tutela jurisdicional sem dilações indevidas e o julgamento antecipadíssimo da lide. Revista de Processo. São Paulo, Revista dos Tribunais, ano XXXI, n 141, p. 158, nov. 2006.

${ }^{8}$ GAJARDONI, Fernando da Fonseca. Técnicas de aceleração do processo. São Paulo: Lemos e Cruz, 2003. p. 60. 
Respeitadas todas estas posições, certo é que a razoável duração consiste no tempo necessário para instruir completamente o processo, observando todas as exigências legais e atentando-se, ao mesmo tempo, para que a morosidade processual não cause danos às partes.

A Constituição Federal garantiu, além do direito à razoável duração do processo, os meios necessários à efetivação de tal garantia, como por exemplo, direito de petição. Prevê, também, dentre outras coisas, que "não será promovido o juiz que, injustificadamente, retiver autos em seu poder além do prazo legal, não podendo devolvê-los ao cartório sem o devido despacho ou decisão".

A EC no 45/2004, em seu art. $7^{\circ}$, estabeleceu que, imediatamente, após a sua promulgação, o Congresso Nacional instalaria uma comissão especial mista para elaborar projetos de lei regulamentando a matéria nela tratada, bem como modificar a legislação federal, com o objetivo de ampliar o acesso à justiça e acelerar a prestação jurisdicional.

\subsection{Acesso à justiça}

A garantia do acesso à justiça, prevista no art. $5^{\circ}$, inciso XXXV da Constituição Federal, assegura que toda lesão e ameaça de direito serão apreciadas pelo Poder Judiciário, não podendo a lei prever o contrário. Cumpre destacar as lições de Mauro Capelletti e Bryant Garth, ambos especialistas em acesso à justiça:

A expressão "acesso à Justiça" é reconhecidamente de difícil definição, mas serve para determinar duas finalidades básicas do sistema jurídico - o sistema pelo qual as pessoas podem reivindicar seus direitos e/ou resolver seus litígios sob os aspúcios do Estado. Primeiro, o sistema deve ser igualmente acessível a todos; segundo, ele deve produzir resultados que sejam individual e socialmente justos. ${ }^{9}$

Alguns autores como Kazuo Watanabe e Alexandre Freitas Câmara dizem que não basta garantir o acesso à justiça, mas sim o acesso à ordem jurídica justa. Esclarecendo o tema, Alexandre Freitas Câmara aduz que:

A garantia de acesso à ordem jurídica justa, assim, deve ser entendida como a garantia de que todos os titulares de posições jurídicas de vantagem possam ver prestada a tutela jurisdicional, devendo esta ser prestada de modo eficaz, a fim de se garantir que a referida tutela seja

\footnotetext{
${ }^{9}$ CAPELlETTI, Mauro; GARTH, Bryant. Acesso à justiça, trad. bras. Ellen Gracie Northfleet, Porto Alegre: Sergio Antonio Fabris, 1988. p. 8.
} 
capaz de efetivamente proteger as posições de vantagem mencionadas. ${ }^{10}$

A doutrina, influenciada pelo jurista italiano Mauro Capelletti ${ }^{11}$, reconhece três fases do acesso à justiça. A primeira consiste na luta pela assistência judiciária gratuita para aqueles que não possam arcar com as despesas decorrentes (hoje assegurada na CF, art. 5, LXXIV). A segunda onda visou proteger os interesses meta-individuais, como os difusos e coletivos. Nesse ponto, o Brasil possui diversos instrumentos de proteção, como o mandado de segurança coletivo, ação civil pública e a ação popular.

Quanto ao terceiro momento tem-se o chamado "novo enfoque do acesso à justiça". Visa buscar a satisfação do jurisdicionado que recorre ao Poder Judiciário para tutelar interesses. É a fase que atualmente ocorre, na qual se busca tornar este Poder mais ágil e eficiente. Destacam-se, aqui, as reformas processuais que estão sendo implementadas.

Nesse diapasão, o acesso à justiça não pode ser restrito a garantir a propositura de uma ação judicial por qualquer pessoa, mas, também, deve compreender a razoável duração do processo. Com efeito, quanto maior o lapso de tempo decorrido até a solução definitiva da lide, menor e mais fraca será sua eficácia, fragilizando cada vez mais o direito.

Desta forma, torna-se imperioso incluir no preceito de acesso à justiça, o direito à saída do processo, ou seja, o direito de ter tutelado pelo Poder Judiciário a sua pretensão em tempo ainda de surtir os efeitos esperados, pois o Estado tomou para si, com exclusividade, essa obrigação e deve, portanto, realizá-la pronta e eficazmente. Nesse sentido, ensina Gelson Amaro de Souza:

\begin{abstract}
O acesso ao judiciário deve ser entendido como sendo o ingresso com alguma demanda quando o interessado utiliza-se do instituto da ação. É a postulação que se faz ao Judiciário. No entanto, acesso à justiça é bem diferente. Ao contrário do ingresso junto ao Poder Judiciário, o acesso à Justiça é a saída, com o seu direito satisfeito. Ingressar no judiciário é em até certo ponto fácil, mas o difícil é ter acesso à Justiça; isto é, sair do processo com a pretensão satisfeita dentro de um lapso de tempo razoável. Essa satisfação da pretensão dentro de um prazo razoável, sem desperdício de tempo e dinheiro é o que se pode falar em acesso à Justiça. ${ }^{12}$
\end{abstract}

Luiz Guilherme Marinoni também comunga o entendimento de que:

\footnotetext{
${ }^{10}$ CÂMARA, Alexandre Freitas. Lições de direito processual civil. 16. ed. Rio de Janeiro, Lumen Juris, 2007. v. I. p. 36.

11 Cf. CAPELLETTI, Mauro; GARTH, Bryant. Acesso à justiça, trad. bras. Ellen Gracie Northfleet, Porto Alegre: Sergio Antonio Fabris, 1988.

12 SOUZA, Gelson Amaro de. Fraude à execução sobre nova visão. Revista Nacional de Direito e de Jurisprudência, Ribeirão Preto-SP, Ano V, nº 55, p. 34, jul. 2004.
} 
$\mathrm{O}$ direito à defesa, assim como o direito à tempestividade da tutela jurisdicional, são direitos constitucionalmente tutelados. Todos sabem, de fato, que o direito de acesso à justiça, garantido pelo artigo $5^{\circ}$, XXXV, da Constituição da República, não quer dizer apenas que todos têm direito de ir a juízo, mas também quer significar que todos têm direito à adequada tutela jurisdicional ou à tutela jurisdicional efetiva, adequada e tempestiva. ${ }^{13}$

Seguindo estas idéias, a Convenção Européia para proteção dos Direitos Humanos e Liberdades Fundamentais reconheceu, expressamente, que a Justiça que não cumpre suas funções dentro de um prazo razoável é uma justiça inacessível (art. $6^{\circ}, \S 1^{\circ}$ ).

Verifica-se, assim, que a celeridade processual está intimamente ligada ao acesso à justiça, pois este é completamente garantido quando, além de permitir o acesso ao Poder Judiciário, assegurar a tramitação do processo em tempo razoável para que a decisão de mérito seja prolatada em momento que ainda interesse às partes.

\section{Repercussão geral no recurso extraordinário para o Supremo Tribunal Federal}

O Supremo Tribunal Federal é o órgão de cúpula do Poder Judiciário, composto por onze ministros, e a ele compete, precipuamente, a guarda da Constituição Federal, conforme definido em seu art. 102.

Sua competência é fixada na $\mathrm{CF}$, sendo que, no âmbito recursal, julga, em recurso ordinário, o habeas corpus, o mandado de segurança, o habeas data e o mandado de injunção decididos em única instância pelos Tribunais Superiores, se denegatória a decisão, e, em recurso extraordinário, as causas decididas em única ou última instância, quando a decisão recorrida contrariar dispositivo da Constituição.

Assim como todo Poder Judiciário, seu órgão máximo não fica de fora da crise. $\mathrm{O}$ sitio do STF na internet oferece estatísticas da movimentação processual naquela Corte, pelo qual se percebe que no ano de 2007, foram protocolados 119.324 processos e, até junho de 2008, foram 54.877 processos. Desses 119.324 processos em 2007, 49.708 são decorrentes de recursos extraordinários. ${ }^{14}$

A Suprema Corte norte-americana, tribunal nacional de cúpula dos Estados Unidos da América, que se serviu de inspiração ao STF no Brasil, ao entrar crise decorrente do

\footnotetext{
13 MARINONI, Luiz Guilherme. Tutela antecipatória e julgamento antecipado. 5. ed. São Paulo: Revista dos Tribunais, 2002. p. 18.

14 Supremo Tribunal Federal: Estatísticas. Brasil. Disponível em: <http://www.stf.gov.br/portal/ cms/verTexto.asp? servico=estatistica\&pagina=movimentoProcessual >. Acesso em: 25 mar. 2008.
} 
grande número de processos que recebia, instituiu “a petitions for writ of certiorari” requisito do recurso referente ao critério subjetivo de relevância que a causa deveria ter para todo país.

\subsection{Recurso extraordinário}

A Carta Magna em seu artigo 102, III estabelece a competência do Supremo Tribunal Federal para julgar o recurso extraordinário, que é disciplinado, também, no Código de Processo Civil nos artigos 541 ao 546. É originário do direito norte americano e representa o recurso de acesso ao órgão supremo do Poder Judiciário da Federação Brasileira.

O recurso extraordinário vem para corrigir a ofensa a dispositivos constitucionais e, também, como arma do STF para uniformizar a jurisprudência do ordenamento jurídico nacional no que tange à interpretação daqueles, além de que é o modo de controle difuso de constitucionalidade. Com toda propriedade, manifesta-se Fredie Didier Jr. e Leonardo da Cunha que:

Enfim, o papel do recurso extraordinário, no quadro dos recursos cíveis, é o de resguardar a interpretação dada pelo STF aos dispositivos constitucionais, garantindo a inteireza do sistema jurídico constitucional federal e assegurando-lhe validade e uniformidade de entendimento. ${ }^{15}$

Tem por objeto qualquer decisão de única ou última instância proferida por juiz ou tribunal desde que presente as hipóteses de cabimento, previstas nas alíneas a, b, c e d do art. 102, III da CF, ou seja, decisão que contrariar dispositivo da Constituição, que declarar a inconstitucionalidade de tratado ou lei federal, que julgar válida lei ou ato de governo local contestado em face da Constituição e que julgar válida lei local contestada em face de lei federal (última hipótese introduzida pela Emenda Constitucional n ${ }^{\circ} 45$ de 2004).

A interposição do recurso extraordinário somente possui efeito devolutivo, conforme expressamente dispõe o art. $542, \S 2^{\circ}$ do CPC, mas a sua decisão acaba possuindo um efeito transcendente, ou seja, ela além de se referir às partes, vincula outros juízos hierarquicamente subordinados. Sobre o tema já se manifestou Mantovanni Colares Cavalcante:

Uma das questões mais graves no direito processual, e que tem gerado intensa controvérsia doutrinária, diz respeito à transcendência da decisão emanada dos Tribunais Superiores, no sentido de viabilizar um alargamento no raio de ação do que é decidido no âmbito do

15 CUNHA, Leonardo José Carneiro da; DIDIER JR, Fredie. Curso de direito processual civil. 5. ed. Salvador: Podivm, 2008. v. III. p. 306. 
recurso excepcional, extrapolando os limites da própria causa, de modo a vincular outras decisões semelhantes em processos sequer submetidos à instância especial. ${ }^{16}$

Este efeito não é imposto pela legislação brasileira, mas por uma questão de lógica os órgãos inferiores ao STF, na sua maioria, acabam seguindo suas orientações. Isso porque se o órgão hierarquicamente superior entende daquela forma, a decisão de um inferior que a contrarie poderá ser reformada, em grau de recurso. Assim, para evitar impugnações, costuma-se decidir em consonância com a jurisprudência dos Tribunais Superiores.

Diversas são as manifestações deste fenômeno que destaca a prevalência dos posicionamentos adotados pelo STF. Como exemplo cita-se, a súmula vinculante, que será editada após reiteradas decisões daquele órgão sobre a questão constitucional. Corroborando tal entendimento, também, o parágrafo $3^{\circ}$ do art. 475 do CPC dispensa o reexame necessário, quando a sentença se baseia em posicionamento tomado pelo Pleno do Supremo.

\subsection{Repercussão Geral}

A EC no 45/2004 acrescentou o $\S 3^{\circ}$ ao art. 102 da Constituição Federal, introduzindo um novo instituto ao ordenamento jurídico brasileiro chamado de repercussão geral das questões constitucionais, que serve como uma nova exigência para que o Supremo Tribunal Federal admita o recurso extraordinário.

Posteriormente, em 19 de dezembro de 2006, surgiu a Lei $\mathrm{n}^{\circ} 11.418$ regulamentando-o, inclusive acrescentando ao CPC os artigos 543-A e 543-B. Por esse motivo, o Regimento Interno do STF também foi adaptado através da Emendas Regimentais $\mathrm{n}^{\circ} 21$, de 23 de março de 2007, e $\mathrm{n}^{\circ} 23$, de 11 de março de 2008.

De acordo com o $\S 3^{\circ}$ do art. 102 da Magna Carta, “o recorrente deverá demonstrar a repercussão geral das questões constitucionais discutidas no caso, nos termos da lei”. Tereza Arruda Alvim Wambier, Luiz Rodrigues Wambier e José Miguel Garcia Medina explicam com muita precisão tal disposição legal:

Ou seja, precisará demonstrar que o tema discutido no recurso tem uma relevância que transcende aquele caso concreto, revestindo-se de interesse geral, institucional, semelhante ao que já ocorria, no passado,

\footnotetext{
16 CAVAlCANTE, Mantovanni Colares. Recurso especial e extraordinário. São Paulo: Dialética, 2003.
} p. 173. 
quando vigorava no sistema processual brasileiro, o instituto da argüição de relevância. $^{17}$

Traduz a repercussão geral numa espécie de filtro que selecionará os casos em que o interesse vai além do individual, ou seja, a importância da decisão transcenda àquela causa em que o recurso foi interposto.

Não há uma definição clara e direta sobre o que viria a ser repercussão geral, em vista de tratar-se de conceito vago ou indeterminado. No entanto, a doutrina aponta algumas diretrizes para identificá-la, citando, como exemplo, o fato de o tema dizer respeito a um grande número de pessoas ou estar ligado a valores considerados fundamentais, como vida e a liberdade.

O $\S 1^{\circ}$ do art. 543-A do CPC estabelece que "para efeito da repercussão geral, será considerada a existência ou não de questões relevantes do ponto de vista econômico, político, social ou jurídico, que ultrapassem os interesses subjetivos da causa". Fornece, assim, alguns parâmetros para averiguar se a causa possui ou não interesses que vão além dos das partes litigantes.

É praticamente consenso, entre os doutrinadores, que a repercussão geral possui natureza de requisito de admissibilidade do recurso extraordinário. Da simples leitura do art. $102, \S 3^{\circ}$ da CF já se constata que o instituto servirá para que o tribunal examine a admissão do recurso.

Frise-se que antigamente vigorava, no Brasil, o sistema de argüição de relevância em recurso extraordinário. Este se iniciou em 1975, com a emenda ao Regimento Interno do Supremo, onde era previsto, e foi extinto com a CF em 1988.

Com este instituto era preciso argüir a relevância da matéria versada no recurso extraordinário. Apesar de algumas semelhanças com a repercussão geral, as decisões referentes a argüição de relevância eram secretas e não demandavam motivação.

A filtragem dos casos que a Suprema Corte julgará não é novidade em âmbito internacional, tendo em vista a existência de institutos semelhantes em diversos outros países como EUA, Argentina e Japão.

O CPC e o Regimento Interno do STF cuidam do processamento da repercussão geral. Estabelece o art. 543-A do CPC, que o recorrente, para ver seu recurso extraordinário conhecido, deverá demonstrar, em preliminar, para apreciação exclusiva do Supremo Tribunal Federal a existência da repercussão geral.

\footnotetext{
${ }^{17}$ MEDINA, José Miguel Garcia Medina; WAMBIER, Luiz Rodrigues; WAMBIER, Tereza Arruda Alvim. Breves comentários à nova sistemática processual civil. 3. ed. São Paulo: Revista dos Tribunais, 2005. p. 97.
} 
Como a apreciação é exclusiva do STF, o Tribunal de origem não se manifestará e a decisão sobre a existência ou não de repercussão geral é irrecorrível. Destarte, o $\S 3^{\circ}$ do referido artigo estabelece casos expressos de existência deste requisito, qual seja, de recurso que impugnar decisão contrária à súmula ou jurisprudência dominante do Tribunal.

Convém anotar que somente a existência de repercussão geral não significa que o recurso extraordinário será recebido. É necessário, ainda, o preenchimento dos demais requisitos genéricos e especiais deste tipo de recurso. A apreciação da existência ou não da repercussão geral ocorrerá somente após a análise dos outros requisitos.

Caberá ao Plenário, nos termos do art. 102, parágrafo $3^{\circ}$ da $\mathrm{CF}$, declarar a ausência de repercussão geral, pela manifestação de dois terços de seus membros. ${ }^{18}$ A respeito do tema, explica com grande sabedoria Fredie Didier Jr. e Leonardo José Carneiro da Cunha:

O quorum qualificado é para considerar que a questão não tem repercussão geral. "É razoável afirmar, assim, que existe uma presunção em favor da existência de repercussão geral". Se for interposto o recurso extraordinário e este contiver um item ou tópico em que se demonstre (se firme) a repercussão geral, passa, então, a haver uma presunção: presume-se que há repercussão geral, somente cabendo ao plenário do STF (por dois terços do seus membros) deixar de conhecer do recurso extraordinário por falta de repercussão geral. ${ }^{19}$

O CPC dispõe que, se a Turma decidir pela existência do requisito por, no mínimo quatro votos, ficará dispensada a remessa do recurso ao Plenário. Com efeito, se o Supremo é composto por onze ministros, quatro deles representam mais que um terço e, sendo assim, não se forma o quórum de dois terços exigidos para negar a repercussão geral.

A decisão do Plenário, negando a existência de repercussão geral, valerá para todos os recursos sobre matéria idêntica, que serão indeferidos liminarmente. Nesses casos (e apenas neles) o presidente do Tribunal a quo, ou o relator monocraticamente ou a Turma do STF poderão, em juízo de admissibilidade, negar a presença de repercussão geral.

Em caso de multiplicidade de recursos com fundamento em idêntica controvérsia, a análise da repercussão geral será processada nos termos do Regimento Interno do Supremo

18 O STF decidiu, em 11 de junho de 2008, que o dispositivo da repercussão geral poderá ser aplicado pelo Plenário da Corte a RE que discutem matérias já pacificadas pelo STF, sem que esses processos tenham de ser distribuídos para um relator. Assim, os recursos que versem sobre matérias já julgadas pelo STF serão enviados para a Presidência deste, que levará a questão ao Plenário antes da distribuição do processo. Caberá aos ministros, no julgamento colegiado, aplicar a jurisprudência da Corte, rediscutir a matéria ou simplesmente determinar o seguimento normal do recurso, caso se identifique que a questão não foi ainda discutida pelo Plenário.Supremo Tribunal Federal: Notícias dia 11.06.2008. Brasil. Disponível em: <http://www.stf.gov.br/portal/cms/verNoticiaDetalhe.asp?idConteudo=90964\&tip=UN>. Acesso em: 12 jun. 2008. 
Tribunal Federal, observado o disposto no art. 543-B do CPC. ${ }^{20}$

Caberá ao Tribunal de origem selecionar um ou mais recursos representativos da controvérsia e encaminhá-los ao STF, sobrestando os demais até julgamento definitivo da Corte. Negada a existência de repercussão geral, os recursos sobrestados considerar-se-ão automaticamente não admitidos. Isso é conhecido como julgamento por amostragem.

Por conta disso surgiu a figura do amicus curiae, prevista no art. 543-A, $\S 6^{\circ}$ do CPC. Segundo consta, pode o relator admitir, na análise da repercussão geral, a manifestação de terceiros, subscrita por procurador habilitado, nos termos do Regimento Interno do Supremo. Visa com isso permitir que outras pessoas, que também serão afetadas pela decisão de existência de repercussão geral, possam se manifestar. Humberto Theodoro Júnior afirma que:

O interesse que legitima essa intervenção não é o da parte recorrente. Esta age na defesa de interesse próprio. O amicus curiae desempenha um papel institucional, atuando como colaborador do tribunal na apuração de valores maiores que possam estar em jogo na interpretação da regra constitucional envolvida no recurso. ${ }^{21}$

Quando daquela apreciação da repercussão geral por amostragem, for reconhecida a existência dela, julgar-se-á o mérito da ação. Nesse caso, caberá aos Tribunais locais apreciar os recursos sobrestados nos termos do $\S 3^{\circ}$ do art. 543-B do CPC.

De acordo com este, se a decisão recorrida estiver em conformidade com a decisão do STF, será, o recurso extraordinário, declarado prejudicado. Agora, se estiver em contrariedade com o entendimento do Supremo, poderá haver retratação, através da qual o órgão julgador local poderá se retratar, alterando o que foi julgado a fim de adequá-lo ao que foi assentado naquele Tribunal.

O CPC, no art. 543-B, $\S 4^{\circ}$, ainda trata a hipótese de a instância local manter a tese contrária à do STF e o recurso extraordinário ser admitido. Determina que poderá este órgão, nos termos do Regimento Interno, cassar ou reformar, liminarmente, o acórdão contrário à decisão firmada.

${ }^{19}$ CUNHA, Leonardo José Carneiro da; DIDIER JR, Fredie. Curso de direito processual civil. 5. ed. Salvador: Podivm, 2008. v. III. p. 313.

${ }^{20}$ O STF decidiu questão de ordem no RE 576155, levantada pelo Ministro Ricardo Lewandowski, permitindo ao relator, quando reconhecida a existência de repercussão geral, determinar o sobrestamento dos processos (em trâmite nos tribunais inferiores) idênticos a outro que esteja com o mérito em análise pela Corte. Supremo Tribunal Federal: Notícias dia 11.06.2008. Brasil. Disponível em: $<$ http://www.stf.gov.br/portal/cms/verNoticiaDetalhe.asp?idConteudo=90965\&tip=UN $>$. Acesso em: 12 jun. 2008.

21 THEODORO JÚNIOR, Humberto. Repercussão geral no recurso extraordinário (lei $\mathrm{n}^{\circ}$ 11.418) e súmula vinculante do Supremo Tribunal Federal (lei no 11.417). Revista IOB de Direito Civil e Processo Civil, Porto Alegre, ano VIII, nº 48, p. 110, jul. - ago. 2007. 
O RISTF, dentro da previsão legal do art. 543-B, concede vários poderes de controle da repercussão geral ao presidente e ao relator. Poderão eles barrar sumariamente o recurso extraordinário que chegar àquela Corte em situação que não apresente, nas razões recursais, preliminar formal e fundamentada de repercussão geral.

Tal regimento, após a ER nº 21/2007, também prevê um procedimento eletrônico de comunicação entre os ministros para debateram sobre existência ou não da repercussão geral. Conforme ensina Humberto Theodoro Júnior,

\begin{abstract}
Para tanto, institui-se um procedimento eletrônico de comunicação entre o Relator do extraordinário e os demais Ministros que compõe o Plenário, o qual prescinde da sessão de julgamento e lavratura de acórdão específico para o incidente da argüição da repercussão geral da questão constitucional debatida. ${ }^{22}$
\end{abstract}

Não se vê nenhuma irregularidade agindo o Supremo através deste procedimento, visto que a Constituição Federal, ao disciplinar a repercussão geral, não exigiu nada além da manifestação de dois terços dos membros. Assim, não se impôs a necessidade de ter uma sessão solene de julgamento pelo Plenário, nem que houvesse lavratura de acórdão. Com isso, buscou-se impedir uma grande burocracia, que atentaria contra o princípio da celeridade processual, norteador da reforma processual introduzida pela EC 45/2004.

\title{
4 Repercussão geral sob a ótica da razoável duração do processo e a garantia do acesso à justiça
}

Tendo em vista que o STF é órgão máximo da Justiça brasileira e que suas decisões acabam influenciando toda a sociedade jurídica, faz-se necessário garantir a ele meios de decidir como órgão supremo, sem se preocupar com casos estritamente particulares.

E é neste contexto que aparece a necessidade da instituição de filtros, como a repercussão geral, para diminuir a quantidade de processos que chegam até aquela Corte e acabam superlotando as pautas, a fim de que os ministros possam ter mais tempo para estudar o caso e decidir com maior segurança e justiça, bem como acelerarem os processos que estão parados a espera de decisão.

Segundo o sítio do STF na internet, em razão da ausência do requisito da repercussão geral, alguns assuntos de pouca relevância deixaram de ser julgados pelo referido órgão, tais 
como a obrigatoriedade de colocação de semáforo em faixa de pedestre e pagamento de indenização por dano moral para torcedor de futebol que se sentiu prejudicado com o rebaixamento de seu time. ${ }^{23}$

Possui, o debatido requisito, as funções de firmar o STF como corte constitucional, e não como mais uma instância recursal, a ensejar só a análise de questões relevantes para a ordem constitucional e fazer com que ele decida apenas uma vez cada questão constitucional. Com isso, diminuirão os recursos extraordinários a serem julgados e acelerará o processamento dos respectivos processos.

Nesse sentido, e com grande sabedoria, Luiz Rodrigues Wambier e outros ao discorrem sobre a repercussão geral aduzem que:

Esta figura impede que o STF se transforme numa $4^{a}$ instância e deve
diminuir, consideravelmente, a carga de trabalho daquele Tribunal,
resultado este que também acaba, de forma indireta, por beneficiar os
jurisdicionados, que terão talvez uma jurisdição prestada com mais
vagar, e haverá acórdãos, já que em menor número, que serão fruto de
reflexões mais demoradas por parte dos julgadores. Enfim, se espera
que, com essa possibilidade de seleção de matérias realmente
importantes, não só para o âmbito de interesse das partes, se tenha
jurisdição de melhor qualidade. ${ }^{24}$

Seguindo esta esteira de dar celeridade aos processos, tanto os que esperam decisão do recurso extraordinário quanto aqueles que não terão de aguardar o trâmite de mais um recurso, por ter sido inadmitido por falta de repercussão, vem este requisito garantir a razoável duração do processo, através de mecanismos que obstam o processamento de recursos extraordinários sem relevância geral.

Além da celeridade processual, o acesso à justiça também é assegurado quando o processo tem uma duração razoável, não postergada em razão de recursos protelatórios. Com efeito, um provimento judicial célere e tempestivo é a realização plena da garantia do acesso à justiça.

Desta forma, pode-se concluir que a repercussão geral está em consonância com a razoável duração do processo e o acesso à justiça, pois permitirá que as decisões sejam

22 THEODORO JÚNIOR, Humberto. Repercussão geral no recurso extraordinário (lei $\mathrm{n}^{\circ}$ 11.418) e súmula vinculante do Supremo Tribunal Federal (lei $\mathrm{n}^{\mathrm{o}}$ 11.417). Revista IOB de Direito Civil e Processo Civil, Porto Alegre, ano VIII, no 48, p. 115, jul. - ago. 2007.

23 Supremo Tribunal Federal: Matérias sem repercussão. Brasil. Disponível em <http://www.stf.gov.br/portal/jurisprudenciaRepercussaoGeral/listarRepercussao.asp?tipo=N> Acesso em: 12 jun. 2008.

${ }^{24}$ MEDINA, José Miguel Garcia; WAMBIER, Luiz Rodrigues; WAMBIER, Tereza Arruda Alvim. Breves comentários à nova sistemática processual civil, 3. São Paulo: Revista dos Tribunais, 2007. p. 241. 
prolatadas em menor lapso de tempo, tempestivamente, assegurando que a justiça realmente seja feita, produzindo os resultados almejados quando da propositura da ação.

Destarte, há posicionamentos contrários à repercussão geral, entendendo-a como retrocesso, devido à colisão com o princípio da ampla defesa, o que, também, acaba impedindo o acesso à Justiça.

Ampla defesa consiste em formas e meios de garantir com que as partes, em litígio, possam se defender de alegações contrárias a seus interesses, trazendo ao processo todos os meios lícitos e admitidos de prova para corroborar suas alegações. Destaca-se que tal direito compete a qualquer das partes, tanto o autor quanto ao réu e que se correlata com o contraditório.

Desta forma, ampla defesa e contraditório, garantidos no art. $5^{\circ}$, inciso LV, devem ser considerados como as oportunidades garantidas às partes de impugnarem as pretensões apresentadas e contrárias as suas. São direitos fundamentais que devem ser rigorosamente observados, juntamente com outros expressamente previstos, em total harmonia do sistema.

Nesse diapasão, entende-se que a filtragem de recursos extraordinários pela repercussão geral não vem prejudicar a ampla defesa, visto que tal recurso é interposto como última medida, depois de um longo trâmite processual, onde as partes tiveram várias oportunidades de apresentar defesa.

Não consiste a ampla defesa em tornar o processo ad infinitum, sempre postergando o resultado final com recursos e meios de impugnação de decisão judicial interpostos pelos sucumbentes inconformados. Visa garantir que durante as fases processuais adequadas haja oportunidade para as partes se defenderem e também alegarem e provarem o que for pertinente.

Ressalta-se que o princípio do acesso à justiça e o duplo grau de jurisdição não são atingidos com a introdução da repercussão geral. Diversamente, o que ocorreu foi um fortalecimento da garantia do acesso à justiça, conforme se falou anteriormente, visto que a celeridade processual almejada permitirá um resultado mais justo se a decisão for tempestiva.

No que toca ao duplo grau de jurisdição, princípio que garante a possibilidade de revisão de uma decisão judicial por um órgão superior, essa forma de filtragem instituída para o recurso extraordinário não lhe prejudica, eis que o STF não é Corte de revisão.

Com efeito, o recurso extraordinário é previsto expressamente na Constituição Federal, art. 102, III, onde também se encontra suas hipóteses de cabimento. Desta forma, este é um recurso limitado que só cabe em algumas situações, devendo o recorrente demonstrar 
que se enquadra nelas. Destaca-se que o recurso sempre é cabível, desde que cumprido os requisitos constitucionais.

O duplo grau de jurisdição é garantido quanto aos recursos ordinários, ou seja, aqueles previstos para se interpor de uma decisão judicial de primeira instância a um órgão de segunda, sem a exigência do cumprimento de requisitos específicos, bastando a tempestividade e o preparo nos casos em que a lei exige.

Frise-se, ainda, que está havendo um aparente conflito de princípios, pois estes compõem o todo e devem estar harmonizados e não conflitando entre si. Nesse diapasão, ocorrendo choque de princípios, as normas de hermenêutica aduzem que a necessidade de concessões recíprocas, ou seja, cada um cede um pouco até se harmonizarem com todo o sistema. Nas palavras de Marcelo Novelino, necessário se faz a ponderação ${ }^{25}$.

Desta forma, se ocorrer confronto entre razoável duração do processo e algum outro direito ou garantia constitucional deve haver concessões recíprocas para se conciliarem, visto que ambos são constitucionalmente previstos e, portanto, possuem efeitos e aplicabilidade imediata sobre tudo.

\section{Repercussão geral na prática}

Desde a introdução da repercussão geral no ordenamento jurídico brasileiro pela Emenda Constitucional $\mathrm{n}^{\mathrm{o}} 45$ de 08 de dezembro de 2004, diversos posicionamentos favoráveis e desfavoráveis surgiram por parte dos juristas e da doutrina.

A exigência deste pressuposto de admissibilidade ocorre para os recursos extraordinários interpostos de acórdãos publicados a partir de 03 de maio de 2007, data da vigência da $E R n^{\circ} 21 / 2007$, que foi quem regulamentou de forma completa o processamento deste novo instituto, de acordo com o que já estabelecia a CF e o CPC.

Frise-se que quanto aos recursos extraordinários anteriores a isto, a sua admissibilidade é feita de acordo com as disposições que vigiam antes do requisito da repercussão geral. Agora, quanto aos múltiplos, tanto os posteriores quanto os anteriores, estão sujeitos ao sobrestamento, retratação e reconhecimento de prejuízo, conforme disciplina o art. 543-B do CPC. ${ }^{26}$

\footnotetext{
${ }^{25}$ Cf. NOVELINO, Marcelo. Direito constitucional. 2. ed. São Paulo: Método, 2008. p. 245.

${ }^{26}$ Supremo Tribunal Federal: Repercussão geral. Brasil. Disponível em: $<$ http://www.stf.gov.br/portal/cms/verTexto.asp?servico=jurisprudenciaRepercussaoGeral\&pagina=vigencia $>$. Acesso em 30 jun. 2008.
} 
É um tema, que por ser recente, será melhor aprofundado e disciplinado com o passar do tempo, visto que a lei e o RISTF deixaram lacunas que deverão ser integradas pelo Supremo como já está ocorrendo. Com isso ficará mais assente a regulamentação da parte técnica e operacional, bem como as questões que possuem ou não repercussão geral.

Diversos doutrinadores coadunam com o entendimento de ter sido esta introdução de grande proveito para diminuir no Supremo Tribunal Federal o número de processos decorrentes de recurso extraordinário.

Luiz Rodrigues Wambier, Tereza Arruda Alvim Wambier e José Miguel Medina entendem ser bastante elogiável a reintrodução de instituto semelhante à antiga argüição de relevância. ${ }^{27}$ Nessa mesma orientação, Alexandre Freitas Câmara salienta que:

\begin{abstract}
A criação desse requisito é, a nosso juízo, elogiável, já que faz com que o Supremo Tribunal Federal, Corte Suprema do País, só se debruce sobre causas realmente relevantes para a Nação. Não faz sentido que o Pretório Excelso perca seu tempo (e o do País) julgando causas que não tem qualquer relevância nacional, verdadeiras brigas de vizinhos, como fazia antes da EC 45/2004. ${ }^{28}$
\end{abstract}

Dentro das características favoráveis destacam-se, além da diminuição de recursos, a celeridade processual em contrapartida a morosidade, referente a acabar com a espera de um novo julgamento, bem como permitir ao STF julgar como órgão supremo e, também, garantir o acesso à justiça, no sentido de o litigante ter sua lide resolvida pelo Poder Judiciário em curto espaço de tempo.

Verificando estatísticas fornecidas pelo Supremo Tribunal Federal ${ }^{29}$, constata-se que, após 03 de maio de 2007, começou a cair o número de recursos extraordinários distribuídos sem preliminar de repercussão geral e, de modo contrário, a subir os que possuíam tal preliminar.

Também, depois daquela data, iniciou-se o sobrestamento dos processos na origem em razão de recursos extraordinários com fundamento em idêntica controvérsia, nos termos do art. 543-B do CPC, o que produziu os efeitos almejados, eis que chegou a zerar a distribuição destes. É o que ocorreu com os recursos extraordinários sobre telecomunicações

\footnotetext{
${ }^{27}$ Cf. MEDINA, José Miguel Garcia; WAMBIER, Luiz Rodrigues; WAMBIER, Tereza Arruda Alvim. Breves comentários à nova sistemática processual civi. 3. ed. São Paulo: Revista dos Tribunais, 2005. p. 98.

${ }^{28}$ CÂMARA, Alexandre Freitas. Lições de direito processual civil. 14. ed. Rio de Janeiro: Lumen Juris, 2007. v. II. p. 141.

${ }^{29}$ Supremo Tribunal Federal: Estudo sobre repercussão geral no recurso extraordinário. Brasil. Disponível em: $<$ http://www.stf.gov.br/portal/jurisprudenciaRepercussaoGeral/arquivo/estudoRepercussaoGeral.pdf $>$. Acesso em: 30 maio 2008.
} 
(serviços de telefonia - fatura - discriminação de pulsos), bem como com aqueles que têm assuntos ligados à prescrição de cobrança de dívida ativa em execução fiscal.

Ressalta-se que é de grande valia o instrumento de sobrestamento quando houver multiplicidade de recursos com fundamento em idêntica controvérsia, tendo em vista que são distribuídos muitos recursos idênticos para serem julgados. Por exemplo, no período de julho a novembro de 2007 foram distribuídos, dentre outros assuntos, 134 recursos sobre serviços de telefonia e 117 sobre vencimentos de militares ${ }^{30}$.

O STF disponibiliza, na internet, a relação de matérias já julgadas que possuem ou não repercussão geral. De tal forma, isso facilita todos os jurisdicionados, que podem conferir se já houve julgamento de matéria semelhante a que versa seu processo, a fim de saber se convém ou não interpor recurso extraordinário.

Dezenas de assuntos já têm reconhecida a sua repercussão geral, tais como os recursos que discutiam alíquota progressiva no imposto sobre transmissão causas mortis; inelegibilidade de ex-cônjuge de prefeito reeleito; direito adquirido na contagem do tempo de serviço especial posterior à EC 20 de 1998 para fins previdenciários; competência para executar as contribuições previdenciárias decorrentes de todo período laboral; etc $^{31}$.

Nestes processos, reconheceu-se que a questão constitucional versada no recurso extraordinário possui interesse que ultrapassa os limites subjetivos da causa e, portanto, serão objeto de análise de mérito pela Suprema Corte, visto que poderá interessar a todos que estão ou estarão naquela situação.

Ficou comprovada a importância das matérias onde se reconheceu a repercussão geral, haja vista que foram editadas súmulas vinculantes sobre algumas delas. É o caso da súmula vinculante $\mathrm{n}^{\mathrm{o}} 6^{32}$, onde o STF reconheceu a repercussão geral do tema e entendeu que é constitucional o pagamento de valor inferior ao salário mínimo para os jovens que prestam serviço militar obrigatório.

Por outro lado, o STF deixou de receber recursos por entender que a matéria não possuía repercussão geral. Reconheceu-se a ausência desta em ação que questionava a

\footnotetext{
${ }^{30}$ Supremo Tribunal Federal: Estudo sobre repercussão geral no recurso extraordinário. Brasil. Disponível em: $<$ http://www.stf.gov.br/portal/jurisprudenciaRepercussaoGeral/arquivo/estudoRepercussaoGeral.pdf>. Acesso em: 30 maio 2008.

$31 \quad$ Supremo Tribunal Federal: Estudo sobre repercussão geral no recurso extraordinário. Brasil. Disponível em: $\quad$ <http://www.stf.gov.br/portal/jurisprudenciaRepercussaoGeral/arquivo/estudoRepercussaoGeral.pdf>. Acesso em: 30 maio 2008.

32 Supremo Tribunal Federal. Súmula Vinculante $n^{\circ}$ 6: "Não viola a Constituição o estabelecimento de remuneração inferior ao salário mínimo para as praças prestadoras de serviço militar inicial".
} 
constitucionalidade da Lei municipal $n^{\circ} 2.740 / 2001$, que obriga a instalação de semáforo com dispositivo de acionamento pelos próprios pedestres, nas faixas nela especificadas.

Desta feita, constata-se a importância que o novel requisito de admissibilidade do recurso extraordinário possui. Em pouco tempo de vigência, já produziu efeitos esperados, ou seja, diminuiu a distribuição de processos, simplificou a análise de recursos semelhantes em caso de multiplicidade e inadmitiu diversos recursos extraordinários que não debatiam sobres matérias que oferecessem repercussão geral.

Com estes resultados positivos da repercussão geral, está-se desafogando o STF, de forma que será possível promover a celeridade processual, tanto dos processos que não terão que esperar um novo julgamento de recurso, quanto dos processos que lá esperam por decisão, em respeito ao princípio da razoável duração do processo, propiciando desta forma um verdadeiro acesso à justiça, com satisfação das partes litigantes.

\section{CONCLUSÃO}

A EC n 45/04 visando realizar reformas no Poder Judiciário, assombrado pela morosidade processual, introduziu, dentre várias inovações, a garantia à razoável duração do processo e o instituto da repercussão geral das questões constitucionais para o recurso extraordinário.

A comentada reforma constitucional garantiu expressamente no rol de direitos e garantias fundamentais o direito à celeridade processual ao estabelecer que o processo deve ter uma duração razoável.

Junto a isto, instituiu a repercussão geral para o recurso extraordinário, ou seja, um novo requisito constitucional (art. 102, $\S 3^{\circ}$ da $\mathrm{CF}$ ) visando filtrar recursos que chegam ao STF, para admitir somente aqueles onde a matéria transcenda o interesse exclusivo das partes.

Desta forma, só serão admitidos recursos extraordinários quando os ministros da referida Corte entenderem que existem questões relevantes do ponto de vista econômico, político, social ou judiciário que ultrapassem o interesse subjetivo da causa. Essa aferição será feita nos moldes estabelecidos pela Lei ${ }^{\circ} 11.418 / 06$ no CPC (arts. 543-A e 543-B) e pelas Emendas Regimentais n 21/07 e n² 23/08.

Com isso, busca-se diminuir o grande número de processos que chegam ao STF todos os dias e reconduzir esta Corte a sua verdadeira função, que é resolver questões de grande relevo para o país. 
Destaca-se que o procedimento do referido instituto comporta aspectos, como julgamento por amostragem, em caso de multiplicidade de recurso com fundamento em idêntica controvérsia, e o indeferimento liminar de recursos que versam sobre matéria idêntica a outros, nos quais não foi reconhecida a repercussão geral, que diminuem substancialmente a tarefa dos julgadores.

A repercussão geral vem servir ao princípio da razoável duração do processo na medida em que inadmite os recursos protelatórios e garante que os processos sejam mais céleres, tanto os que tiveram o recurso inadmitido, pois não precisarão mais esperar por nova decisão, como também naqueles que estão no próprio STF à espera de decisão.

A par disto, garantido também está o acesso à justiça, visto que este comporta o acesso ao judiciário, bem como a solução tempestiva do processo, capaz de produzir eficácia entre as partes.

Não se pode alegar que a repercussão geral afronta outros direitos e garantias fundamentais, como a ampla defesa, e o duplo grau de jurisdição. Destarte nenhum direito é absoluto e deve ser ponderado para estar harmonizado com o todo.

As estatísticas fornecidas pelo STF demonstram que, definitivamente, está-se filtrando os recursos que lá chegam, a fim de julgar somente as matérias realmente relevantes nacionalmente e fazer com que aquela Corte recupere a sua verdadeira função constitucional.

Conclui-se que a repercussão geral, selecionando os recursos extraordinários a serem julgados, promove a razoável duração do processo, no âmbito do STF, tanto daqueles que não esperarão outro julgamento, como dos que esperam julgamento, mas agora com pautas menos lotadas, garantindo, assim, o verdadeiro acesso à justiça, com a solução tempestiva da lide.

\section{REFERÊNCIAS BIBLIOGRÁFICAS}

BRASIL. Supremo Tribunal Federal. Disponível em: <http://www.stf.gov.br $>$. Acesso em: 10 fev. 2008.

BRASIL. Supremo Tribunal Federal: Estudo sobre repercussão geral no recurso extraordinário.

<http://www.stf.gov.br/portal/jurisprudenciaRepercussaoGeral/arquivo/estudoRepercussaoGe ral.pdf>. Acesso em: 30 maio 2008.

CÂMARA, Alexandre Freitas. Lições de direito processual civil. 16. ed. Rio de Janeiro, Lumen Juris, 2007. v. I.

CAPELLETTI, Mauro; GARTH, Bryant. Acesso à justiça, trad. bras. Ellen Gracie Northfleet, Porto Alegre: Sergio Antonio Fabris, 1988.

CAVALCANTE, Mantovanni Colares. Recurso especial e extraordinário. São Paulo: Dialética, 2003.

CUNHA, Leonardo José Carneiro da; DIDIER JR, Fredie. Curso de direito processual civil. 5. ed. Salvador: Podivm, 2008. v. III. 
GAJARDONI, Fernando da Fonseca. Técnicas de aceleração do processo. São Paulo: Lemos e Cruz, 2003.

- O princípio constitucional da tutela jurisdicional sem dilações indevidas e o julgamento antecipadíssimo da lide. Revista de Processo. São Paulo, Revista dos Tribunais, ano XXXI, $n^{\circ} 141$, nov. 2006.

MARINONI, Luiz Guilherme. Tutela antecipatória, julgamento antecipado e execução imediata da sentença. São Paulo: Revista dos Tribunais, 1997.

MEDINA, José Miguel Garcia Medina; WAMBIER, Luiz Rodrigues; WAMBIER, Tereza Arruda Alvim. Breves comentários à nova sistemática processual civil. 3. ed. São Paulo: Revista dos Tribunais, 2005.

NOVELINO, Marcelo. Direito constitucional. 2. ed. São Paulo: Método, 2008.

SOUZA, Gelson Amaro de. Fraude à execução sobre nova visão. Revista Nacional de Direito e de Jurisprudência, Ribeirão Preto-SP, ano V, nº. 55, jul. 2004.

THEODORO JÚNIOR, Humberto. Curso de direito processual civil. 46. ed. Rio de Janeiro: Forense, 2007. v. I.

. Repercussão geral no recurso extraordinário (lei $\mathrm{n}^{\circ} 11.418$ ) e súmula vinculante do Supremo Tribunal Federal (lei $\mathrm{n}^{\circ}$ 11.417). Revista IOB de Direito Civil e Processo Civil, Porto Alegre, ano VIII, nº 48, jul.-ago 2007.

TUCCI, José Rogério Cruz e (org.). Garantias constitucionais do processo civil: Homenagem aos 10 anos da Constituição Federal de 1988. São Paulo: Revista dos Tribunais, 1989.

WAMBIER, Teresa Arruda Alvim et al (orgs.). Reforma do judiciário. São Paulo: Revista dos Tribunais, 2005. 